\title{
Arms trade and weapons export control
}

\author{
Marina Aksenova ${ }^{1}$
}

\section{Introduction}

Arms trade is a notoriously opaque sphere of business activity because it involves immense financial flows and is tightly linked to the conduct of governmental agencies granting arms export licenses. The cost-benefit analysis for the state pondering the decision to grant an export license to a certain manufacturer within its borders includes factors such as diplomatic relations with the country receiving the weapons, financial incentives, the relationship with other states supplying arms (especially in the context of consortium producers located in different exporting states), the projection of power in the political arena, and human rights and humanitarian law implications of such decision. Until very recently, the transnational regulation of arms trade has been patchy at best: only a handful of regional instruments of a binding and non-binding nature regulated weapons export control. The Arms Trade Treaty or 'ATT', which entered into force at the end of 2014, changed this status quo (ICRC, 2016).

This contribution explores the implications of the ATT and other legal instruments regulating the trade in weapons in relation to the extraterritorial obligations (ETOs) of states. The discussion expands on the overall starting premise of this volume, namely that the traditional territorial model of attributing human rights obligations is reaching its limits due to globalization and ensuing mutual interdependence of various state and non-state actors. Weapons trade is no exception to this trend. In this regard, it is helpful to refer to the Maastricht Principles on Extraterritorial Obligations of States in the Area of Economic, Social, and Cultural Rights (2013) ('Maastricht Principles'), which tend to go beyond territorial conception of responsibility by demanding that states act in a way so as to reduce the risk of impairing the enjoyment of rights extraterritorially (Principle 13) and cooperate internationally in realizing these rights (Principle 8(b)). The Maastricht Principles call on states to adopt and enforce measures to protect rights in a variety of scenarios, including when the corporation is domiciled in a state concerned (Principle 25(c)).

Weapons trade engages many stakeholders across jurisdictions. It clearly includes states on the supply side of the spectrum that grant licenses and authorizations to producers and manufacturers located on their territory. It is often the case that corporations in question work in consortiums, meaning that different parts of the equipment are produced in different countries. 
Weapons are then delivered to a state on the receiving end, which may, in turn, use this equipment in a military campaign in yet another country. Such interrelatedness creates a complex web of mutually reinforcing commitments, which may be difficult to tease apart based on a purely territorial model of establishing human rights obligations. The context of ETOs allows for an expanded analysis of the issue.

This chapter utilizes a specific example to shed light on the nature of obligations arising out of weapons trade: it focuses on potential responsibility of several European arms exporters to the Saudi/UAE-led coalition which is engaged at the time of this writing in an armed conflict in Yemen (Bryk and Saage-Maaß 2019). The communication by the European Centre for Constitutional and Human Rights (ECCHR) filed to the International Criminal Court (ICC) in 2019 alleges potential complicity of corporate and state officials located on the territory of the signatories of the Rome Treaty of the ICC and the ATT, namely Spain, Italy, the UK, Germany, and the United Kingdom, in humanitarian law violations in Yemen for knowingly and purposefully aiding the coalition in the commission of crimes in Yemen.

The following section of the chapter engages with the general legislative framework for weapons trade with the view of establishing standards according to which states grant licenses for exporting military equipment. This section draws links between the Maastricht Principles governing states' extraterritorial obligations in the area of human rights (ETOs) and the existing legal regulation of weapons trade. Section 3 focuses on questions of corporate responsibility in the context of arms trade. It engages with the ECCHR submission to the ICC to the extent that some general conclusions - for instance, regarding the standard of knowledge necessary to trigger individual responsibility - may be deduced. The final section of the chapter offers some concluding observations.

\section{Legal framework for states' obligations}

\section{International law}

The ATT is the key legal document regulating international arms trade at the state level, representing the first comprehensive treaty addressing this issue of global concern. The ATT was initiated in 2006 by the UN General Assembly (UNGA) Resolution in response to the absence of any common international standard for the transfer of conventional arms that might contribute to the devastating human consequences of armed conflict. This regulatory gap undermined peace, reconciliation, safety, security, stability, and sustainable social and economic development (UNGA 2006). Responding to this pressing problem, the UNGA began the process of examining the feasibility of a thematic treaty. The process ultimately resulted in the adoption of the ATT on 2 April 2013. The treaty subsequently came into force on 24 December 2014. At the moment of writing, 109 states have ratified the treaty and 31 states have signed but have not yet ratified it.

In terms of numbers, five out of the world's top ten largest exporters of arms have ratified the ATT. These states are France, Germany, Spain, United Kingdom, and Italy. The United States, which is the number one supplier of weapons in the world, initially signed the treaty but later revoked its intention to be bound by it, as announced by the US administration in 2019 (Brown 2019). The ATT was therefore never legally binding on the US. Nationals of the five countries that ratified the ATT and thus agreed to be subjected to an international review process are currently under scrutiny in the submission filed by the ECCHR to the ICC requesting the Court to open a preliminary examination into the conduct of European arms suppliers. 
The main aspiration of the ATT as stipulated in Article 1 is to establish the highest possible common international standards for regulating international trade in conventional arms, which includes combat aircrafts, missiles, large-caliber artillery systems, warships, and other items. There is also a subtler underlying rationale for the treaty, namely, to prevent arms from falling into the 'wrong hands' and thereby to reduce human suffering. The ATT aims to accomplish the overarching goal of establishing a high standard for regulating the arms trade by requiring exporting countries to carry out a thorough and comprehensive risk assessment before engaging in such activity. This requirement strongly resonates with a similar one contained in the Maastricht Principles, namely an obligation incumbent on states to avoid causing harm, where such harm is foreseeable (Principle 13) and the accompanying obligation to conduct prior risk assessment of potential impact of state's laws and policies on the extraterritorial enjoyment of rights (Principle 14).

The evaluation procedure under the ATT includes examining the risk of human rights violations in the country of destination (art. 7), the risk of diversion of the exported arms (art. 11), and the possible adverse impact on internal and regional stability (art.11(2)). In addition to that, and for the sake of transparency, the countries are obligated to report their arms exports and imports annually (art. 13). This latter commitment is echoed in the Maastricht Principle 2, which also requires states to observe the principles of transparency and accountability.

Article 6 of the ATT deals specifically with authorizations of conventional arms transfers by the state. It captures a variety of possible scenarios, including a ban on authorizing transfers that would violate measures adopted by the UN Security Council under Chapter VII of the Charter of the United Nations, specifically arms embargoes (art. 6(1)). The arms embargo has indeed been instated with respect to the situation in Yemen; however, it only concerns transfers of weapons to the Houthi rebel groups but not to the coalition (UN Security Council 2015).

Article 6(2) of the ATT also prohibits the supply of arms in cases when such action 'would violate its relevant obligations under international agreements to which it is a Party, in particular those relating to the transfer of, or illicit trafficking in, conventional arms'. This norm appears to be generic in its attempt to cover any activity that falls short of the obligations arising out of the ATT and other instruments relating to arms control, such as the Nuclear Non-Proliferation Treaty, the Biological and Toxin Weapons Convention, and the Chemical Weapons Convention (art. 2(1)(b); EU Council 2008). It is interesting to note that the commentaries to the ATT suggest that a qualifier 'in particular' in the text of Article 6(2) ATT points to the fact that not only thematic treaties but also treaties of a more general application are included within the ambit of this provision, including the UN Charter, which stipulates the principle of non-intervention and the principle of non-use of force under Article 2(4) (Casey-Maslen et al. 2016). The obligations arising from the UN Charter would thus make transfers of weapons to non-state actors illegal given the ruling of the International Court of Justice in Nicaragua that 'training, arming, equipping, financing and supplying the contra forces or otherwise encouraging, supporting and aiding military and paramilitary activities in and against Nicaragua' (ICJ 1986, para. 292).

The commentaries also suggest that Article 6(2) ATT may encompass human rights treaties, such as the 1966 International Covenant on Civil and Political Rights (ICCPR) or the European Convention on Human Rights (ECHR) (Casey-Maslen et al. 2016). Article 6 of the ICCPR and Article 2 of the ECHR guarantee the right to life, and weapons transfers may indeed violate this right (Casey-Maslen et al. 2016). That being said, the commentaries further note that the scope of the right to life has been tested in the context of the ECHR when the applicant challenged Italy's supply to Iraq of 'lethal weapons' during the regime of Saddam Hussein. The ruling of the European Court on Human Rights pointed out that no right to have the transfer of arms regulated or other such measures taken by a state party to the ECHR is 
'as such guaranteed by the Convention' (ECtHR 1995). It thus remains to be seen how broadly Article 6(2) of the ATT would be interpreted in individual cases.

Finally, and more specifically, the ATT implies a certain level of compliance with the norms of international humanitarian law as it provides in Article 6(3) that a State Party shall not authorize any transfer of conventional arms:

(...) if it has knowledge at the time of authorization that the arms would be used in the commission of genocide, crimes against humanity, grave breaches of the Geneva Convention of 1949, attacks directed against civilian objects or civilians protected as such, or other war crimes as defined by international agreements to which it is a Party.

It is therefore mandatory in this situation to refuse to grant a license. It is noteworthy that Article 6(3) refers to explicit knowledge existing at the time of the granting of the license that weapons would be used to commit crimes. The earlier draft of the same provision prohibited granting licenses 'for the purpose' of facilitating the commission of international crimes. This initial phrasing presumed an even higher threshold of mens rea for the supplying state. The original text was later updated to refer to 'knowledge' rather than 'purpose' due to the difficulty of demonstrating that a state supplies weapons intending the commission of international crimes (Casey-Maslen et al. 2016). Nonetheless, even the knowledge requirement that was ultimately adopted is rather difficult to ascertain when it comes to factual evidence - the degree and specificity of such knowledge remains to be defined on a case-by-case basis. One practical pitfall of such a generalized definition of knowledge is that arms export licenses usually cover a range of products to be delivered over the course of months or even years. It may so happen that the recipient state can plausibly demonstrate that these supplies will be used to pursue legitimate aims. At the same time, it is possible that a certain proportion of the delivered weapons and ammunition would eventually be diverted to the commission of war crimes or crimes against humanity. The question remains as to the degree of scrutiny and vigilance to be exercised by the granting authorities of the ATT State Party in such a scenario.

The ATT provides for an additional safety net when it comes to the requisite knowledge of the granting State Party. Even if the authorities of the supplying state do not meet the standard for awareness described in Article 6(3), they are still obligated under Article 7 ATT to assess the potential that the conventional arms could be used to commit or facilitate serious violations of international humanitarian law. If after conducting such an assessment and considering available mitigating measures, the exporting state party determines that there is an overriding risk of such consequences, the exporting state party shall not authorize the export (art. 7(3)). The ATT therefore requires quite a high level of scrutiny when it comes to authorizing weapons exports as it includes both knowledge of the actual crimes committed with the said weapons as well as the risk of their commission.

\section{Regional law}

As mentioned in the beginning of this chapter, prior to the entry into force of the ATT the regulation of arms trade had been patchy. Key binding regional instruments include the 2008 European Union (EU) Council Common Position on arms export controls (EU Council Common Position 2008) and the 2006 Economic Community of West African States (ECOWAS) Convention on Small Arms and Light Weapons, Their Ammunition, and Other Related Materials (Kinshasa Convention 2010). There are also non-binding regional guidelines for controlling arms transfers, such as the 2005 Central American Integration System (SICA) Code of Conduct 
of Central American States on the Transfer of Arms, Ammunition, Explosives, and Other Related Materiel; the 2005 Best Practice Guidelines for the implementation of the Nairobi Declaration and the Nairobi Protocol on Small Arms and Light Weapons; and the 2000 Organization for Security and Co-operation in Europe (OSCE) Document on Small Arms and Light Weapons.

The EU Council Common Position contains obligations similar to those enshrined in the ATT in that it requires the EU member states to assess the recipient country's attitude towards relevant principles established by instruments of international humanitarian law and deny an export license if there is a clear risk that the military technology or equipment to be exported might be used in the commission of serious violations of international humanitarian law (art. $2(2)(c))$. Despite the similarity between the ATT and the EU Council Common Position, the latter document arguably contains an obligation of an even higher level of scrutiny of potential risks arising out of arms supplies as compared to the former. The EU Council Common Position requires the risk of serious violations of international humanitarian law to be 'clear'. In contrast, the Article 7(3) of the ATT uses the term 'overriding', which may point towards a higher level of the burden of proof.

The Maastricht Principles talk about the 'real' risk of the violations of human rights, which is a 'foreseeable' result of state's conduct (Principle 13). Commentaries to the Maastricht Principles further clarify that the term 'real' refers to the probability of a certain result materializing namely, only ascertainable risks are included. 'Foreseeable result' is then either the result that was actually foreseen or should have been foreseen based on prior assessment (De Schutter et al. 2012). Arguably, both the terms 'clear' and 'real' with reference to potential risks leave considerable amount of discretion in establishing the level of awareness in each specific case.

\section{Domestic regulation}

Lastly, domestic regulatory framework for arms exports must be mentioned. National rules usually identify specific competent authorities in each country responsible for granting or rejecting arms export licenses and what additional conditions may apply beyond the common rules of the ATT and the EU Common Position. In this regard, it is peculiar that authorization practice by the EU Member States over recent years exhibits significant divergences. This can be explained by the lack of sufficiently clear regulatory guidance as well as actual deviation from the standards set out in the EU Council Common Position and the ATT (Schliemann and Bryk 2019). Diverse regulatory landscape, which frequently departs from or misinterprets international guidance results in fragmentation. This discrepancy in turn allows the governments excessive flexibility in complying with the rule, prohibiting authorization of arms exports where there is a risk of their subsequent use for violations of international human rights or humanitarian law. Determination of the foreseeability of risk appears to be a normative question open to be resolved by each state according to idiosyncratic criteria.

Such disparity becomes especially apparent in relation to European arms exports to members of the Saudi-led coalition involved in the conflict in Yemen (Schliemann and Bryk 2019). One example of the flexibility afforded to states exporting weapons in the context of the situation in Yemen is a challenge launched in the UK in 2017 by the Campaign Against Arms Trade (CAAT) against the Secretary of State for International Trade. CAAT requested judicial review of licensing decisions relating to military exports to Saudi Arabia, which might later be used in the conflict in Yemen. The claimants argued that the body of evidence available in the public domain not only suggested but also dictated the conclusion that such a clear risk exists, thereby making it unlawful to continue exporting weapons to Saudi Arabia. The UK High Court dismissed the claim (High Court of Justice 2017). 
CAAT's subsequent appeal against this decision was partially upheld in 2019 when the UK Court of Appeal ruled that the Secretary acted 'irrationally' by failing to reach a view on whether there had been a pattern of international humanitarian law (IHL) violations by Saudi Arabia and its coalition partners in Yemen (High Court of Justice 2017). This cautious judgment did not determine whether the granting of licenses in this case was lawful or not, but rather focused on the process by pointing out the need to assess the historic pattern of breaches of IHL by Saudi Arabia and its coalition partners. The Court's decision therefore did not suspend any existing licenses but rather invited further scrutiny. Adhering to this ruling, the UK Secretary of State for International Trade pledged to conduct such an assessment. In July 2020, the Secretary of State for International Trade, Liz Truss, announced that following the examination of the relevant data 'there is not a clear risk that the export of arms and military equipment to Saudi Arabia might be used in the commission of a serious violation of IHL'. The UK government therefore recommitted to supplying military equipment to the coalition. The government also withdrew its appeal to the Supreme Court, possibly to avoid further examination of the matter.

CAAT's challenge in the UK courts demonstrates the reluctance of the government to submit to high standard of mens rea with respect to granting of the licenses with potential humanitarian or human rights law implications. It also shows the difficulty of litigating human rights law-based claims within the regulatory landscape of arms trade. The following section shifts focus to potential corporate responsibility in the context of arms trade, while retaining the view encompassing states' ETOs.

\section{Obligations of corporate actors}

\section{The ECCHR Communication}

On 11 December 2019, the ECCHR together with a group of other NGOs submitted a communication to the Office of the Prosecutor of the ICC urging for the opening of a preliminary examination into the conduct of several European companies, based in the UK, Spain, Italy, Germany, and France, that supply weapons to the Saudi/UAE-led coalition ('ECCHR Communication') (Aksenova and Bryk 2020). This document alleges that fighter jets and other military equipment furnished by these companies were used in indiscriminate attacks against civilian objects in Yemen since March 2015. These actions of arms exporters may potentially fall under the definition of several specific war crimes enshrined in the Rome Statute of the ICC, including violence to life and person and directing attacks against the civilian population. More specifically, the ECCHR Communication refers to Articles 8(2)(c)(i), and 8(2)(e)(i), (ii), (iii), and (iv) of the Rome Statute of the ICC.

To provide some context, it is important to note that the war in Yemen started in 2014 when Houthi insurgents took control of Yemen's capital and largest city, Sana'a. They overthrew the government of the Saudi-backed leader, President Abd Rabbu Mansour Hadi, and installed their own rule in large parts of the country including the capital. This takeover prompted a coalition of Gulf states led by Saudi Arabia to launch a campaign in 2015 of economic isolation and air strikes against the Houthi insurgents, with logistical and intelligence support from major world powers including the United States. Other countries, most notably, Spain, Italy, the United Kingdom, Germany, and the UK, also supplied military equipment to the Saudi-led coalition. These parties to the conflict exacerbated what the UN referred to as the world's largest humanitarian catastrophe with estimates of more than 100,000 people killed since 2015 (Global Conflicts Tracker 2020). 


\section{Increased focus on responsibility of corporate actors}

The timing of the ECCHR Communication to the ICC corresponds to the increasing demand on companies to comply with their obligations under international humanitarian and human rights law. The Krupp and IG Farben trials by the US Military Tribunal at Nuremberg and the case of $Z$ yklon B by the British Military Courts were the first attempts to hold individual industrialists to account for complicity in crimes committed during the Second World War. Despite the fact that several domestic jurisdictions allow for criminal responsibility of corporate entities, international criminal law continued developing along the individual responsibility track ever since the initial industrialists' trials. It is noteworthy that the French proposal to include criminal responsibility of corporations in the Rome Statute of the ICC was not accepted at the conference that drew up the document. Nonetheless, the Statute contains two elaborate articles on modes of liability (arts. 25 and 28) that provide for legal tools to attach responsibility to individuals, including those acting on behalf of corporations.

Recent regional and global developments attest to the fact that the conversation on international corporate criminal liability is not closed. From a sociological perspective, the proliferation of social media activism ensures that increased attention is given to climate change issues and corporate contribution to it. This development invites additional scrutiny of the conduct of multinational corporations in mineral rich areas and the impact of their activities on the environment.

From a legal perspective, additional avenues for prosecutions of corporate entities and individuals are opening up: the Malabo Protocol on Amendments to the Protocol on the Statute of the African Court of Justice and Human Rights adopted on 27 June 2014 and now open for ratifications explicitly extends its jurisdiction to legal persons in Article 46(C) (van Sliedregt 2019). The UN Guiding Principles on Business and Human Rights also instruct corporations to avoid, prevent, and mitigate adverse human rights impacts that are directly linked to their business activities, and in that respect conduct human rights due diligence (Office of the High Commissioner of Human Rights 2012).

The difficulty with the UN Guiding Principles is that they constitute what is called 'soft law' and are therefore not binding under international law stricto sensu. The UN Guiding Principles nonetheless provide a solid foundation for the increased recognition of corporate due diligence obligations in the area of human rights incumbent on companies. Moreover, the UNGP also recognize that states have discretion to enact legislation with extraterritorial reach to rein in their corporations. The draft treaty on the human rights obligations of transnational corporations, currently elaborated by a Working Group of the UN Human Rights Council, is testament in this regard (Human Rights Commission 2019). The Working Group is preparing a treaty that will translate some aspects of the UN Guiding Principles into hard law directed at states by prompting them to enact domestic legislation to ensure compliance of corporations with human rights law. It must be noted, however, that the treaty, as it stands now, will address states and is not likely to impose direct obligations on corporations. Thus, even if a treaty is enacted, the UN Guiding Principles will continue to ensure that companies, at the very least, risk high reputational costs for violating due diligence obligations in the area of human rights and international law.

Despite these developments, however, prosecutions, let alone convictions, of individuals acting out of their corporate capacity or corporations as such, for their potential complicity in international crimes, are rare even at the domestic level (Zerk 2013). One widely cited ruling that is relevant for the present discussion is the Van Anraat case decided by the Dutch courts in 2005. The case before the District Court of The Hague was brought by the Dutch Prosecutor 
against Van Anraat, a chemicals dealer who sold thiodiglycol to Saddam Hussein's regime, which was used in the production of mustard gas. The Court acquitted Van Anraat of genocide due to the lack of the specific intent but convicted him of complicity in war crimes (District Court of The Hague 2005).

\section{Obligations of corporate actors in the context of arms trade}

The ECCHR Communication draws attention to the obligations of corporate actors in the context of arms trade. However, the supply of weapons is only possible due to express authorizations issued by various states. As previously mentioned, the ATT - ratified by all of the states in question - permits trade in weapons but sets out a number of limitations. For instance, Article 6(3) of the ATT expressly prohibits the authorization of the transfer of arms if the state party has knowledge that the arms would be deployed in the commission of international crimes.

Given the complexity of current transnational corporate structures and the varying scope of licenses granted to companies exporting weapons to Saudi Arabia and other coalition members, the degree and specificity of knowledge about the crimes committed with these weapons needs to be evaluated based on factual evidence. The purpose of the ECCHR Communication is thus to invite further scrutiny of the conduct of corporate actors providing continued support to the coalition that includes not only the supply of weapons but also their ongoing maintenance. One of the crucial questions linked to potential responsibility of corporations in this case is the existence of express state authorization in the form of licenses to export weapons.

The lack of coherence at the level of granting authorities has direct impact on businesses engaged in weapons trade as the arms industry is not directly bound by the ATT and the EU Common Position, and thus relies heavily on the decisions by state authorities. State consent may thus be invoked by corporations to eschew due diligence obligations incumbent on companies, which are required to assess the risk of potential human rights violations resulting from their activities. Therefore, the lack of clear regulatory guidance gives rise to divergence from the positive elements of the standards set out by the EU Common Position and the ATT (Schliemann and Bryk 2019). This situation has direct bearing on states' ETOs as it engages the Maastricht Principles, which expressly require states to adopt measures to protect rights when the threat of harm originates in their territory or when the corporation facilitating such harm is domiciled in the state concerned (Principle 25(a) and (c)). The Maastricht Principles thus impose a positive duty on a state to be proactive in situations when corporations located on its territory are at risk of causing harm extraterritorially.

The challenge with holding corporations accountable for weapons trade lies not only in the existence of state approval for such activity under the licensing regime but also in the nature of business activity as such. Corporations seldom perpetrate international crimes directly since the motive for multinational companies contributing to human rights abuses is usually that of either financial gain or minimization of losses in the context of existing partnerships (Prosansky 2007). The goal is often not to directly engage militarily or support one of the warring parties but rather to conduct successful business operations with a side effect of facilitating violations of human rights. The motive of financial gain obscures the link between specific corporate officials and the ultimate resulting crimes. The connection is further muddled by the fact that companies most frequently knowingly or unknowingly assist in human rights abuses as opposed to being their main perpetrators. Questions of potential complicity thus arise.

Elies van Sliedregt (2019) explains that the level of corporate engagement in international crimes may vary depending on the proximity of corporate influence to the end result. The private military company Blackwater - whose staff allegedly tortured prisoners in Iraq may be 
on one side of the spectrum, its contribution to a crime being direct (United States Court of Appeals 2006). In contrast, the type of assistance provided by the Canadian oil and gas producer Talisman Energy could be placed somewhere in the middle of the spectrum. This company was charged under the US Alien Tort Claims Act with aiding persecution of civilians in Sudan by virtue of investing in the country's oil industry amidst the civil war. Talisman Energy provided logistical support to state-run militia by building roads and airfields with the aim of protecting its oil reserves (United States Court of Appeals 2009).

Finally, the other side of the spectrum of possible corporate complicity in violations of international human rights and humanitarian law encompasses 'continuous silent approval' by corporations trading with dictatorial regimes. These businesses endorse authoritarian regimes in exchange for the financial benefit they derive from such cooperation (van Sliedregt 2019). In this case, culpability arises from the fact that corporate officials deliberately closed their eyes to what would otherwise have been obvious. In other words, their knowledge may be inferred according to the standard of 'willful blindness', adopted as a form of requisite intent in some jurisdictions (United States Court of Appeals 1992). Arguably, weapons trade frequently falls under the latter category - arms exporters deliberately avoid examining the end use of their products, preferring to focus solely on the relationship between the supplier and the ordering state.

\section{Challenges of holding corporate actors accountable at the ICC}

Article 25(3)(c) of the Rome Statute of the ICC is one of the key provisions invoked in the ECCHR Communication as it establishes responsibility of those who:

...for the purpose of facilitating the commission of such a crime, aids, abets or otherwise assists in its commission or its attempted commission, including providing the means for its commission.

The question of complicity of corporate actors within the meaning of Article 25(3)(c) appears to be 'ICC specific', yet the implications underlying the ECCHR Communication may have resonance outside of the scope of this specific situation at the ICC as the move by the ECCHR impacts our general understanding of the degree of corporate obligations in the context of weapons trade. In addition to that, the ECCHR Communication may result in an authoritative interpretation by the ICC of some of the key provisions of the ATT, such as Articles 6(3) and 7.

Article 25(3)(c) definition of complicity calls for a 'purposeful contribution' and it differs from the test developed by the ad hoc tribunals requiring that the aider and abettor simply 'knew (in the sense he was aware) that his own acts assisted the commission of the specific crime in question by the principal offender' (ICTY 2002, para. 71). The wording of 'purposeful contribution' appears to have been borrowed by the Rome Statute drafters from Article 2.06(3) of the US Model Penal Code (MPC) demanding that an accomplice aids 'with the purpose of facilitating the perpetrator's conduct'. Interestingly, the MPC does not set out the standard for a minimal contribution to the crime implying that even a marginal contribution can qualify as complicity provided the 'purpose' requirement is met. This peculiarity balances out the conduct requirement (the effect of the assistance) and the enhanced fault requirement. It seems as if the early ICC case law on the matter follows the same balancing exercise between a lower conduct threshold and a higher threshold for the mental element: the ICC in Bemba held that the level of contribution under Article 25(3)(c) 'does not require the meeting of any specific threshold' (ICC 2016, para. 93). The ad hoc jurisprudence, in contrast, demanded from accomplices 
'substantial contribution to the crime, which the judges clarified to be a fact-based inquiry' (e.g. ICTY 2010, para. 1741).

It remains to be seen how the ICC interprets 'purposeful contribution' in the context of the ECCHR Communication. Interestingly, the question of the standard of 'purpose' vs 'knowledge' discussed in the previous section with respect to the ATT Article 6(3) also arises in the context of individual criminal responsibility at the ICC. It is easier to prove the existence of knowledge that crimes may be committed rather than purpose to facilitate their commission when it comes to arms trade. It remains to be seen whether a sui generis approach to mens rea within this ambit of human activity will be adopted. In this regard, it is rather helpful that the ICC offers one important generic clarification regarding the nature of 'purpose' in the Bemba et al. case: the requirement of 'purpose' only applies to the accomplice's attitude towards their own conduct, whereas a more general awareness of crimes to be committed as a result of this conduct would suffice (ICC 2016, paras. 97-98).

It appears that the financial incentives for corporate officials who continuously carry out arms trade with Saudi/UAE-led coalition members in the presence of general awareness of the crimes committed in Yemen (widely and regularly documented by several NGOs, UN agencies, as well as news outlets) could serve as the evidence of 'purpose'. The question to be further examined is whether express authorizations for arms exports given by the respective states to corporations under the licensing regime obviate the existence of fault in corporate officials. The ECCHR Communication argues that they might not. First of all, the licenses do not create a duty for a corporation to export. Secondly, it is foreseeable to corporations that the weapons they supply to the Saudi/UAE-led coalition in Yemen are likely to be used to commit crimes given the abundance of documentation of serious and repeated violations of international humanitarian law committed by the coalition. Finally, one must bear in mind corresponding duties of the exporting states granting such licenses with the knowledge of potential humanitarian law violations. As explained in the previous section, such activity clearly engages states' extraterritorial obligations to protect human rights.

\section{Conclusion}

This contribution examined the legislative framework regulating states' ETOs in the context of arms trade. In addition to that, the chapter purported to shed light on the complex nature of state and corporate involvement in this sector of human activity. It appears that state and corporate responsibility for preventing human rights violations goes hand-in-hand when it comes to supplies of military equipment. Any such equipment has the potential to be used in gross human rights and humanitarian law violations. Questions of risk assessment and knowledge are thus crucial. The ECCHR Communication to the ICC alleging corporate complicity of several European arms exporters in war crimes committed in Yemen served as a case study illustrating specific issues relating to weapons trade.

It is clear that the Maastricht Principles strongly resonate with international instruments regulating arms trade. There is a requirement of transparency and risk assessment of potential extraterritorial harm to human rights (broadly conceived) inherent in these documents. The ECCHR Communication to the ICC demonstrates an increasing pull towards holding corporate officials responsible for their complicity in human rights abuses occurring in foreign states. The picture is however incomplete if one omits states' responsibility in regulating corporate activity in the field of arms trade. Ultimately, the decision to grant authorization to export weapons is taken by states. It is then the degree and specificity of knowledge regarding the risks of violations that comes to the foreground. The Maastricht Principles impose duties on states 
to protect rights in cases when harm may result from the activity of corporations domiciled on its territory. They also impose duties on states to conduct risk assessment when their conduct may lead to a real risk of impairing the enjoyment of rights extraterritorially. The Maastricht Principles therefore bind together states' obligations to protect human rights irrespective of national borders and corporate activity, which is a very promising endeavor in the context of governing arms trade.

\section{Note}

1. marina.aksenova@ie.edu. I would like to thank the editors for their invaluable guidance in preparing this chapter. My gratitude also goes to participants of the ETOs Virtual Authors Meeting of 30 September 2020 and the IE Law Faculty Seminar of 29 October 2020 for their useful feedback on the original draft of this paper. Finally, I would like thank IE student Elvin Gence for her copyediting assistance.

\section{References}

African Union (2008) Protocol on the Statute of the African Court of Justice and Human Rights, available at https://au.int/sites/default/files/treaties/36398-treaty-0045_-_protocol_on_amendments_to_the_ protocol_on_the_statute_of_the_african_court_of_justice_and_human_rights_e-compressed.pdf, last accessed 23 July 2021.

Aksenova, M. and Bryk, L. (2020) Extraterritorial Obligations of Arms Exporting Corporations: New Communication to the ICC', Opinio Juris, available at http://opiniojuris.org/2020/01/14/extraterritorial-obligations-of-arms-exporting-corporations-new-communication-to-the-icc/, last accessed 23 July 2021.

British Military Court (1946) Trial of Bruno Tesch and Two Others, LRTWC, vol. I, Judgment, available at http://www.worldcourts.com/imt/eng/decisions/1946.03.08_United_Kingdom_v_Tesch.pdf, last accessed 23 July 2021.

Brown, D. (2019) 'Trump Says U.S. 'Will Never Ratify' Arms Trade Treaty', Politico, available at https:// www.politico.com/story/2019/04/26/trump-arms-trade-treaty-1385303, last accessed 23 July 2021.

Bryk L. and Saage-Maßß, M. (2019) 'Individual Criminal Liability for Arms Exports under the ICC Statute: A Case Study of Arms Exports from Europe to Saudi-led Coalition Members Used in the War in Yemen', Journal of International Criminal Justice (17), 1117-1137.

Casey-Maslen, S. et al. (eds). (2016) The Arms Trade Treaty: A Commentary, Oxford University Press.

Conference to Review Progress Made in the Implementation of the Programme of Action to Prevent, Combat and Eradicate the Illicit Trade in Small Arms and Light Weapons in All Its Aspects (2006) UN Code of Conduct of Central American States on the Transfer of Arms, Ammunition, Explosives and Other Related Material, A/CONF.192/2006/RC/WP.6, available at http://www.poa-iss.org/RegionalOrganizations/SICA/CentralAmerica-CodeofConduct-English.pdf, last accessed 23 July 2021.

De Schutter, O. et al. (2012) 'Commentary to the Maastricht Principles on Extraterritorial Obligations of States in the Area of Economic, Social and Cultural Rights', Human Rights Quarterly 34, 1084-1169.

District Court of The Hague (2005) Public Prosecutor v. Frans Cornelis Adrianus van Anraat, 09/751003-04, available at http://www.internationalcrimesdatabase.org/Case/178/Van-Anraat/, last accessed 23 July 2021.

European Court of Human Rights (ECtHR) (1995) Tugar v. Italy, Application no: 22869/93, Judgment.

EU Council Common Position (2008) 'Defining common rules governing control of exports of military technology and equipment', 2008/944/CFSP, available at https://eur-lex.europa.eu/legal-content/ EN/TXT/PDF/?uri=CELEX:32008E0944\&from=EN, last accessed 23 July 2021.

Global Conflict Tracker (2020) 'War in Yemen', https://www.cfr.org/global-conflict-tracker/conflict/waryemen, last accessed 23 July 2021. 
High Court of Justice (2017) Campaign against Arms Trade, $R$ (on the application of) $v$. The Secretary of State for International Trade, EWHC 1754, available at https://www.judiciary.uk/wp-content/uploads/2017/07/ r-oao-campaign-against-arms-trade-v-ssfit-and-others1.pdf, last accessed 23 July 2021.

Human Rights Commission (2019) 'Legally Binding Instrument to Regulate, in International Human Rights Law, the Activities of Transnational Cooperation and other Business Enterprises', available at https://www.ohchr.org/Documents/HRBodies/HRCouncil/WGTransCorp/OEIGWG_RevisedDraft_LBI.pdf, last accessed 23 July 2021.

International Committee of the Red Cross (2016) Reference for 'Understanding the Arms Trade Treaty from a Humanitarian Perspective', available at https://icrcndresourcecentre.org/wp-content/ uploads/2016/11/4252_002_Understanding-arms-trade_WEB.pdf, last accessed 23 July 2021.

International Court of Justice (ICJ) (1986) Military and Paramilitary Activities in and against Nicaragua (Nicaragua $v$. United States of America), ICJ Rep. 392, Judgment, available at https://www.icj-cij.org/public/ files/case-related/70/070-19841126-JUD-01-00-EN.pdf, last accessed 23 July 2021.

International Criminal Court (ICC) (2016) Prosecutor v. Jean-Pierre Bemba Gombo, Aimé Kilolo Musamba, Jean-Jacques Mangenda Kabongo, Fidèle Babala Wandu and Narcisse Arido, 'Bemba Judgment', Case ICC01/05-01/13, Judgment Pursuant to Article 74 of the Statute, available at https://www.icc-cpi.int/ CourtRecords/CR2016_18527.PDF, last accessed 23 July 2021.

International Criminal Tribunal for the former Yugoslavia (ICTY) (2002) Prosecutor v. Mitar Vasiljevic, IT98-32-T, Trial Judgment, available at https://www.icty.org/x/cases/vasiljevic/tjug/en/vas021129.pdf, last accessed 23 July 2021.

(2010) Prosecutor v. Vujadin Popovic, IT-05-88-T, Trial Judgment, available at https://www.icty. org/x/cases/popovic/tjug/en/100610judgment.pdf, last accessed 23 July 2021.

Maastricht Principles on Extraterritorial Obligations of States in the Area of Economic, Social and Cultural Rights (2013) available at https://www.fidh.org/IMG/pdf/maastricht-eto-principles-uk_web.pdf, last accessed 23 July 2021.

Office of the High Commissioner of Human Rights (2012) The Corporate Responsibility to Respect Human Rights: An Interpretive Guide, HR/PUB/12/02, available at https://www.ohchr.org/ documents/publications/guidingprinciplesbusinesshr_en.pdf, last accessed 23 July 2021.

Organization for Security and Cooperation in Europe (2000) Document on Small Arms and Light Weapons, https://www.osce.org/fsc/20783, last accessed 23 July 2021.

Prosansky, B. (2007) 'Mining Gold in a Conflict Zone:The Context, Ramifications and Lessons of AngloGold Ashanti's Activities in the Democratic Republic of the Congo', Northwestern Journal of International Human Rights (5), 236, available at https://scholarlycommons.law.northwestern.edu/cgi/viewcontent. cgi?article $=1054 \&$ context $=$ njihr, last accessed 23 July 2021.

Regional Centre on Small Arms and Light Weapons (RECSA) (2005) Best Practice Guidelines for the Implementation of the Nairobi Declaration and the Nairobi Protocol on Small Arms and Light Weapons, http://www.poa-iss.org/RegionalOrganizations/RECSA/Nairobi\%20Best\%20Practice\%20 Guidelines.pdf, last accessed 23 July 2021.

Regional Centre on Small Arms in the Great Lakes Region, the Horn of Africa and Bordering States (RECSA) https://recsasec.org/, last accessed 23 July 2021.

Schliemann, C. and Bryk, L. (2019) 'Arms Trade and Corporate Responsibility: Liability, Litigation and Legislative Reform', Friedrich-Ebert Stiftung Study, available at http://library.fes.de/pdf-files/iez/15850. pdf, last accessed 23 July 2021.

The Arms Trade Treaty (2014) 'Treaty Status', https://thearmstradetreaty.org/treaty-status.html? templateId=209883, last accessed 23 July 2021.

UN General Assembly (2015) Resolution 61/89 'Towards an arms trade treaty: establishing common international standards for the import, export and transfer of conventional arms', A/RES/61/89.

UN Security Council (2015) Resolution 2216, available at https://www.undocs.org/S/RES/2216\%20, last accessed 23 July 2021.

United Nations (2014) Arms Trade Treaty, United Nations Treaty Series, vol. 3013, no. 52373, available at https://www.thearmstradetreaty.org/hyper-images/file/TheArmsTradeTreaty1/TheArmsTradeTreaty. pdf, last accessed 23 July 2021. 
United Nations Office for Disarmament Affairs (UNODA) (2010) Central African Convention for the Control of Small Arms and Light Weapons, their Ammunition, Parts and Components that can be used for their Manufacture, Repair and Assembly (Kinshasa Convention), no. 54327, available at http:// disarmament.un.org/treaties/t/kinshasa/text, last accessed 23 July 2021.

United States Court of Appeals (1992) United States v. Campbell, 977 F.2d 854, available at https://casetext. com/case/us-v-campbell-95, last accessed 23 July 2021.

(2006) Nordan v. Blackwater Security Consulting, LLC, 382 F. Supp. 2d 801, available at https:// casetext.com/case/in-re-blackwater-security-consulting-llc, last accessed 23 July 2021.

(2009) Presbyterian Church of Sudan v. Talisman Energy Inc, 582 5F 3 244, 259, available at http:// www.internationalcrimesdatabase.org/Case/43/Presbyterian-Church-Of-Sudan-v-Talisman-Energy/, last accessed 23 July 2021.

United States Military Tribunal (1949) IG Farben and Krupp Trials, Law Reports of the Trials of War Criminals (LRTWC), vol. X, available at https://www.loc.gov/rr/frd/Military_Law/pdf/Law-Reports_Vol10.pdf, last accessed 23 July 2021.

van Sliedregt, E. (2019) 'Regional Criminal Justice, Corporate Criminal Liability and the Need for NonDoctrinal Research' in Aksenova, M. et al. (eds). Breaking the Cycle of Mass Atrocities: Criminological and Socio-Legal Approaches in International Criminal Law, Hart, last accessed 23 July 2021.

Zerk, J. (2013) Report for Office of the UN High Commissioner for Human Rights on Corporate liability for gross human rights abuses:Towards a fairer and more effective system of domestic law remedies, available at https://www.ohchr.org/Documents/Issues/Business/DomesticLawRemedies/StudyDomesticeLawRemedies.pdf, last accessed 23 July 2021. 